University for Business and Technology in Kosovo

UBT Knowledge Center

Nov 1st, 5:45 PM - 6:00 PM

\title{
Strategic Management Of Secondary Raw Materials In Kosovo As Economical Potencial And Environmental Protection For The Country
}

Ibrahim Krasniqi

University for Business and Technology, ibrakrasniqi@gmail.com

Follow this and additional works at: https://knowledgecenter.ubt-uni.net/conference

Part of the Architecture Commons

\section{Recommended Citation}

Krasniqi, Ibrahim, "Strategic Management Of Secondary Raw Materials In Kosovo As Economical Potencial And Environmental Protection For The Country" (2013). UBT International Conference. 10. https://knowledgecenter.ubt-uni.net/conference/2013/all-events/10

This Event is brought to you for free and open access by the Publication and Journals at UBT Knowledge Center. It has been accepted for inclusion in UBT International Conference by an authorized administrator of UBT Knowledge Center. For more information, please contact knowledge.center@ubt-uni.net. 


\title{
Strategic Management Of Secondary Raw Materials In Kosovo As Economical Potencial And Environmental Protection For The Country
}

\author{
Ibrahim Krasniqi \\ University for Business and Technology, Prishtina, \\ Republic of Kosovo \\ Ibrahim.Krasniqi@ubt-uni.net; ibrakrasniqi@gmail.com
}

\begin{abstract}
The perspective of economic growth, nowadays without promoting an clear environmental protection policy, is no longer possible. However every developing country has to pay so called "ecological bill" in the transition period in order to move through growth and sustainability. Specifically this is an issue if we are talking about the energy raw material impact in ecological conditions and possible new ecologic management that is based on the principles of reducing, reusing and recycling raw material. The main purpose of this work was to analyze the possibility application of lignite fly ash from Kosova Power Plants for the production of self - compacting cement pastes and his use in other industry branches with interest. For the analyses in labor, from the Kosova Power Plants Kosova A and Kosova B in Kastriot were chosen fly ash samples, and the same was tested in the laboratory to show the chances of the application as the additive material and analyzing the exothermal profile of cement pastes with replaced cement from fly ash. The results obtained show that the possibility application of lignite fly ash for the production of self - compacting materials is existing and the same can be used for other industry branches. This is a god opportunity for the use of fly ash as a secondary material which has characteristics of one pozolanic material, with good binder characteristics; it can also clearly improve the rheological properties of fresh concrete and other self - compacting materials.
\end{abstract}

Keywords: strategic management, economic growth, ecological management, raw materials, self-compacting materials and volume changes,

\section{Introduction}

Any product has a possibility of turning into waste when it loses its economic value with the passing of time. Once raw materials are used and waste is created, the properties of the materials are not necessarily lost but can be restored using regenerative processes. Despite the fact that properties of the primary materials have been lost, the waste still carries both the subjective human work and energy used in its production. Differences between the properties of secondary materials (waste) and those of primary raw materials are not substantial; many times these changes are only superficial. The reas on is that primary raw materials often have not undergone fundamental changes during the production process. Waste accumulates over time unless decomposed in the ecosystem or recycled. Today, the accumulation of waste has reached such a magnitude that it can become a real threat to the existence of the whole ecosystem(Li-Teh et al.). The promotion of environmental management and the mission of sustainable development worldwide have exerted the pressure for the adoption of proper methods to protect the environment. All over the world, various researches on economic and ecological profitability of secondary materials recycling in the substitution of raw materials was presented by many authors. Conclusions were presented which suggested that economic viability is likely to occur when the cost of landfilling exceeds the cost of bringing the waste to the recycling center and the cost of using primary aggregates exceeds the cost of using recycled aggregates (Xavier et al. 2006). The rapid industrialization globally has been the main source, bringing in its melee billions of tons of industrial byproducts from many chemical process industries and coal- based thermal power plants. The mineral materials mutely existing in the interior of the earth are mined out and processed into various products, may it be for 
fertilizers, steel or power. As per one study about $8 \%$ of the mined material is only getting converted into usable material and the remaining $92 \%$ is left as byproduct. The natural resources have been used in a squandering way without much concern on the welfare of nature and environment. The harmcaused to the mother earth is insurmountable in this direction. But every cloud has a silver lining. Many of the byproducts befit themselves for the production of building material like bricks, cement and concrete owing to the calcareous, siliceous and/or argillaceous base of the former.

Remnant products of coal are increasingly being used as basis or additives for other industrial sectors. In the world, there are different experiences which have shown achievements in this field. Knowing that utilization of ashes in substituting cement and its sub-products is much known, we will shortly hold on to other experiences which have shown the potentials of using as hes in an adequate manner. In the USA, apart from increasingly being used in construction material industry, ash is being used in paving roads, as a foundation or component of asphalt, in combination with other elements. Also, in Australia, India, China, Germany and other countries, utilization of ashes in such a manner is assuming pace. Since the eighties, when the Japanese found the formula of constructing self-compact concrete, the utilization of ashes has grown considerably as an additive or substitute of cement in many types of constructions, be that a building, a road, a bridge, etc.

Kosovo, with relatively small territory, is one of the richest regions with lignite, and this resource serves as basis for generating the country's energy. In this process, the existing thermal power plans discharge extremely large ash amounts, deposited in superficial landfills, which in turn largely pollute superficial and underground waters, the entire environment. Considering that Kosovo possesses an infrastructure not so modern, and a large demand for development of facilities and road infrastructure, there is quite a great opportunity for using as hes in many segments. As was stated, the Kosovar ashes pertains to the $\mathrm{C}$ class, and based on laboratory analysis, it complies with the majority of criteria of use in diffe rent manners and sectors, as an additive. That for during the work we have made a large number of experiments that show the hydration and temperature behavior of fly utilization and according to the results obtained, we made a conclusions for further possibilities in this field.

\subsection{Production of materials of self-compressing concretes and cement mortars}

Knowing the importance of utilization of fly ash, which comes fromgeneration processes, it was thought of stimulating its use in producing cement and its sub-products, namely in producing self-compressing concretes, then its use in larger projects of infrastructure (roads), and also the promotion of ideas for potential use in other sectors. Here, one must take into account that Kosovo imports large amounts of cement and its sub-products, and in this case it would be very profitable to stimulate a greaterutilization in this sector, since productivity would grow at the one hand, import rates would diminish, and financial means would be saved, and invested in anothersector, on the other hand. Another positive impact from this would be the decreased environmental pollution, which is a problem in itself in Kosovo.

\section{The possibility use of Kosovo secondary raw materials in different fields}

Apart fromconstruction and construction materials, ash may be widely used in other sectors, such as road infrastructure, airport development, agriculture, etc. In the occasion of the development of the Highway which would link Kosovo with Albania, this would present another good case to being using it in the field of road construction, and later utilization would be extended to construction of internal national roads. In other countries such as USA, Britain, Australia, etc., ash has taken the role of a partial substitute of cement in large public facilities, airports (Heathrow - London, Amsterdam, etc.) and the same may be done in constructing Kosovar airports.

In many countries of the world, ashes used also in improving land quality, and enhancing cultivated lands, while on its use as a material for land reclamation in depleted mines there is a great knowledge, and not more room shall be spent to clarify that.

\section{The Experimental Part of Work}




\subsection{Lignite fly ash impact on materials of self-compressing concretes and cement mortars}

In our experimental work, the main aim was to see the possibilities of using Kosovo ash in mortar materials and cement mixtures, specifically focusing on studying volume changes, depending on the amount of ashes and the exothermal behavior of these materials. For the laboratory work, ash samples from different TPP locations in Kosovo were taken to be analyzed for their chemical composition and physical attributes, and studies were made on the particle size and morphology, etc. samples were taken from the TPP-s Kosovo A and B, ash deposits, and also analysis were made on coal-lignite taken from different mining locations, supply storages, and from mills after material preparation.

Chart.1 REM fly ash analysis

\subsection{Chemical and physical analysis of lignite ash}

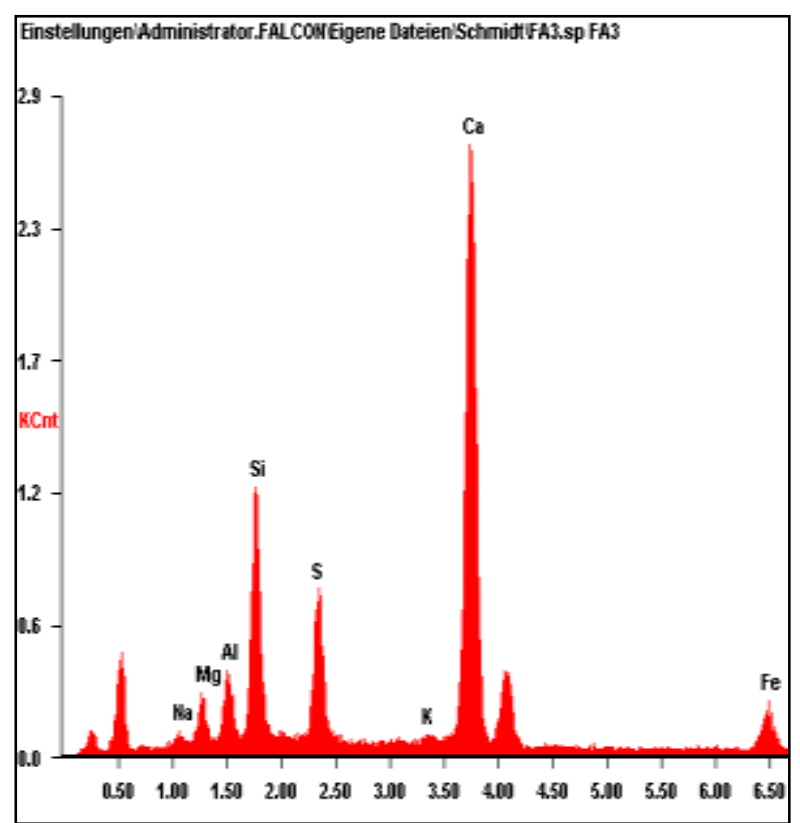

Based on chemical analysis on different samples of Kosovo lignite ash in laboratories, the chemical composition below has resulted (graph 1 and tab.1) and have been presented in an analytical way below

Tab.1-Chemical composition of FA

\subsection{Methodology of the work}

For the development process large number of examples is analyzed in different devices and conditions with specific important point to the study of temperature changes in these samples. It was stated that in Schwindkegel the temperature measurement was directly made, and the data was transferred to the data center, and then transferred into the chart. On the other hand, in the other device Schwindrinne, the temperature was continuously measure during each experiments, but with a different device that was connected.

In general, apart from the impact of the water amount into the sample, the cement type, other additives used (fly ash in our case) and plastification masses, an important role is assigned to the temperature and the hydration process in regards to the material attributes and its processing. Hydration implies that chemical bond of water, and this reaction begins after the water intake into the cement mixture, and on this case a chemical exothermal reaction is registered between water and other components of the sample. This process has a few phases, were in the beginning we have the formation of $\mathrm{Ca}(\mathrm{OH})_{2} \mathrm{In}$ the form of crystals with a hexagonal structure. After one or more hours of reaction development, the hydration processes of a second and third scale begin, and on this case the formation of silicates, hydrates, $\mathrm{CSH}$, etc). as a result of hydration and temperature changes, Different strains are produced, 
and this in turn results into certain volume changes. For this reas on the temperature developments have been analyzed in different samples and in different conditions, and the whole thing was then present ed in respective charts

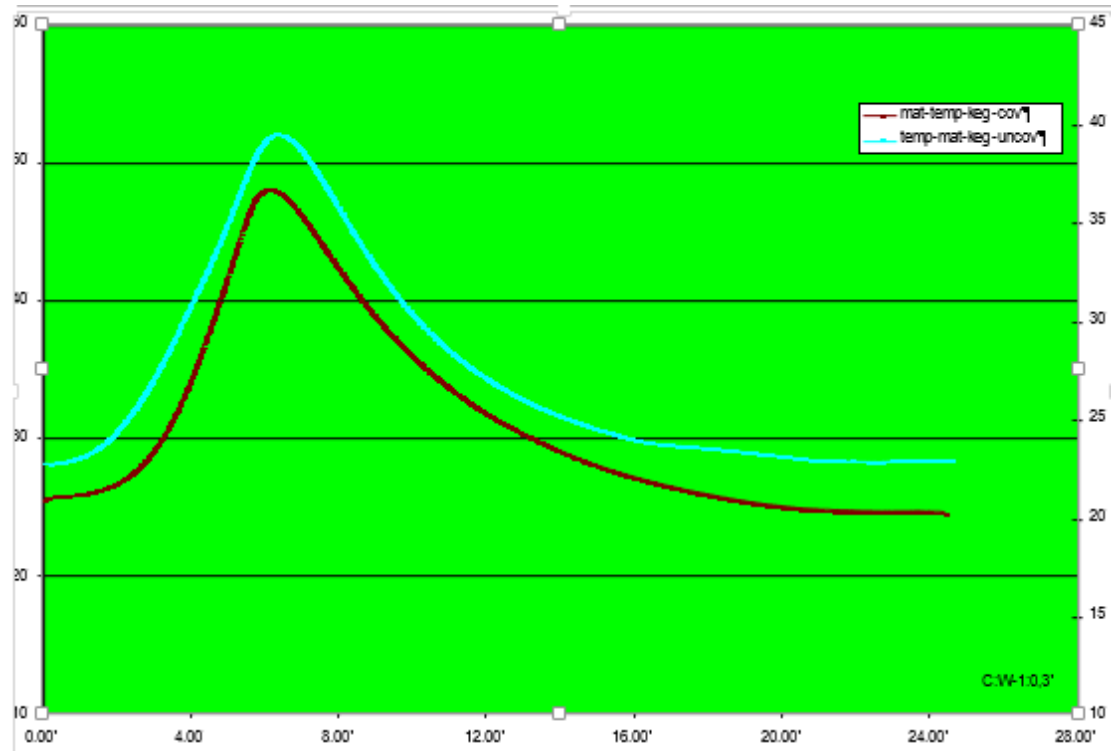

Chart.2. Temperature development in Schwindkegel device (covered/ uncovered)

Due to the utilization of the lignite fly ashes, with a high content of $\mathrm{CaO}$, and also resulting in reactions of $\mathrm{CaO}$ with water in experiments, we have a visible process of hydration, also resulting in considerable early volume changes. The plastic additives provide the possibility for the materials with a relatively small water content gain fluidity and be easier to process, even easier than the conventional. The same reduce the concurrent and inter-particle forces, and eliminate the possibility of creation of agglomerates, strengthening this way the particle dispersion.

On this case the hydration process will be affected, in the way that adding such plastic masses would slow down the creation of new stages of $\mathrm{CSH}$, which means that after the adding of plastic masses, the durability time for cone and stable faces is lengthened. In general, construction materials, including mortars and self-compressing mortars, in the initial stages of solidification process is, are subject to development of a certain temperature, representing thus the hydration process, which depends on the composing stages of cement, which continues until the and of full hydration. The heat of hydration in a construction material is greatly reduced by adding puzzolanic, inert and latent hydraulic materials. Usually, such a process, as seen in experiments made in our case, has a great development in the first two to four hours, and later such a reaction comes to a decline. Also, the temperature of the environment has a certain impact on development of the internal material temperature, and if the external temperature would change for $10 \mathrm{~K}$, then the internal material temperature would even.

Based on our experiments, it can be seen that in the Schwindkegel device, the maximum is usually a cheese and around seven to eight hours after the experiment starts, and this is clearly seen in cement mortars without ashes content low (Graf. 2). After all this time, when one thinks that the fold hydration process has been achieved, and material solidification has already taken the certain shape, the temperature continues to fall, and the after an interval of 24 hours, that returns to the values that almost had when the sample examination began.

Usually the temperature changes are also associated with the changes of internal strains, and such a thing brings early volume changes, which can specifically be spotted in self-compressing cement mortars, and development or the nation and correlation of these two phenomena. Also, it can be seen that a consequence of disallowing the water discharge As a result of covering the same sample, the temperature for the same mixture changes in these conditions, and is higher. 


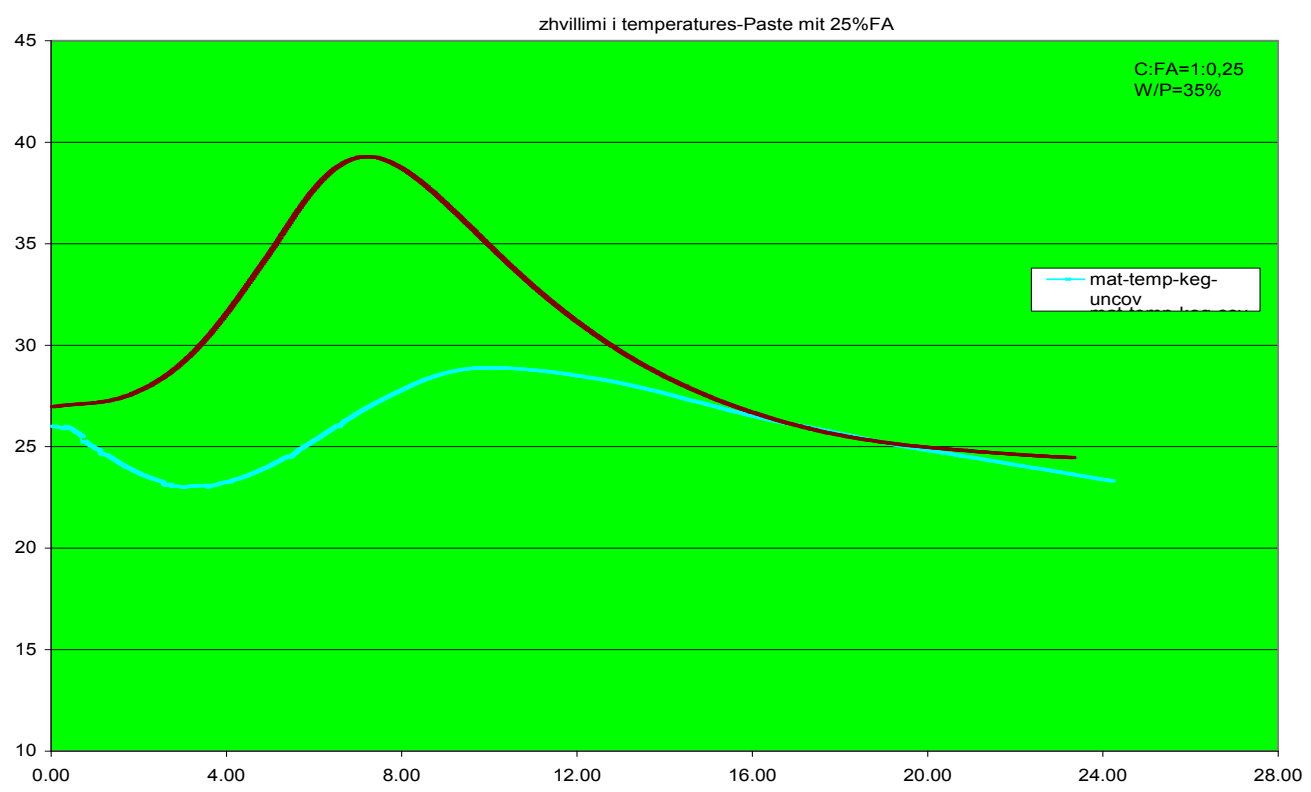

Chart.3. Temperature development in cement pastes with $25 \%$ fly ash

In the chart 3, we can see the temperature changes in cement mortars, where the cement mass is substituted at the $25 \%$ extant with fly ashes, which does not bring a large change, only in the case where the sample is covered by a plastic sheet, the temperature maximum is achieved later when compared to pure cement mortars. Hence, such a temperature peak is achieved after a ten to twelve hours, and is longer than before, not as a result of the ash composition used as the additive, since in this case the times of initial and final solidification are Longer in their start.

By adding the ashes mass up to $50 \%$, then based on the chart 32 the impact of this ash layer is seen even clearer, in temperature evolution and the delay in achieving its maximum development, but in this case there is no clear maximum as in cases above, and temperature development is more constant. So, it may be concluded that the utilization of ashes has a stabilization role, and the hydration process is slower.

\section{Environmental and Economic Benefits}

Concrete is the most common building agent in the world and is the second most consumed resource behind water. The primary binding agent in concrete is portland cement. The production of portland cement accounts for approximately five to seven "percent of the world's carbon dioxide output." "One of the most common and effective" means of reducing these carbon dioxide emissions is to "replace a portion of the portland cement with fly ash." In 2007, the American Concrete Institute found that incorporating fly ash in concrete production resulted in a beneficial 15 million ton reduction of carbon dioxide emissions. Thus, replacing portland cement with fly ash, a material which would otherwise end up in a landfill, serves the dual purpose of limiting the adverse environmental impact of cement production and reducing the fly ash burden on landfills.

Government and industry recognize that to achieve sustainable economic development we need to dramatically improve the efficient use of our natural resources. The need to meet statutory targets for waste reduction, recycling and recovery further strengthens the case for closing the loop on resource use. There are opportunities for improvement throughout the product life cycle. The benefits for business and society start with product design and extend through the efficient use of raw materials and energy to recycling and secondary markets for recovered resources. The benefits of efficient waste and resources management for an organization include minimizing environmental impacts; enhancing 
reputation; complying with regulatory controls; rebates on any climate change agreements; savings from emissions reduction trading; improving resource usage forecasting; and savings on raw material and utility bills.

\section{Conclusions}

Research made and results obtained have shown that in analys is made in samples and different mixtures, and different conditions and devices are rather diverse, and in general it can be concluded that the utilization of Kosovo lignite fly ash in self-compact materials and cement mortars is possible, and may turn useful in many aspects. Temperature behavior in those samples is within technological parameters and according to this it may be concluded also that this type of ashes may be used as a connecting material, and as a substitute of cement, and also as an additive. In our surveys, we have seen that in contradiction with usual information in literature, where usually the use of ash additives has an impact on reduction of water demand, in our case such a thing does not happen, but independent of that, the general parameters remain within allowed limits. The initial and final solidification times are shorter than in cases when ash is not used as an additive, but still remain in allowable limits. As seen by tests and analys is made, volume changes of these materials are evident, but always remaining in acceptable limits, in the technical and technological aspects, while never passing the value of $10 \mathrm{~mm}$ (DIN EN 450 ), even in the case when used as an additive and substitute, the lignite fly ash at the extent of $50 \%$. Also, in materials of self-compact mortars, research made have also shown relatively satisfactory results, and especially in sample mixtures where ash additives are brought to the $30 \%$ extent, then the results are good, and the early volume changes are within the conditions allowed.

The use of lignite ash in materials of construction industry has a positive impact not only in improving hydraulic attributes, but also in improving rheological attributes, as a consequence of its regular particle shape. The negative impact of ash use in material attributes is negligible, as in the case of cement mortars and self-compact mortars. The achievement of stabilizing volume changes in mortar materials and cement mortars remains a task to be resolved with further studies, and for each type of lignite, specific analysis, so that on their bas is their use might proceed. In principle, many authors (Malhotra, Mehta etc) think that in the $21^{\text {st }}$ century, none of the connecting construction materials and other fields should not be produced without including ashes and other secondary materials in their structure.

\section{References}

1. [1] Wittmann,F.: Grundlagen eines Modelles zur Beschreibung charakteristischer Eigenschaften des Betons, DAfStb Heft 290, 1977

2. [2] Setzer, M.J.: Einuss des Wassergehalts auf die Eigenschaften des erharteten Betons, DAfStb Heft 280, 1977

3. [3] Hilsdorf, H.K.: Austrocknung und Schwinden von Beton, RuschFestschrift,W.Ernst\&Sohn, Berlin, 1969

4. [4] Budelmann, H.: Zum Einuss erhohter Temperatur auf Festigkeit und Verformung von Beton mit unterschiedlichen Feuchtegehalten, Dissertation TU Braunschweig, 1987

5. [5] Linjiti i Kosovës -Inkos,Kastriot,1985

6. [6] Tazawa, Ei-ichi: Autogenous Shrinkage of Concrete, Proceedings of the International Workshop, Hiroshima June 13-14 1998, E \& FN Spon London and New York,1999

7. [7] Fleischer,W: Einfluß des Zements auf Schwinden und Quellen von Beton. Dissertation der TU München (1992)

8. [8] Stark,D.: Handbook For The Identification Of Alkali-Silica Reactivity In Highway Structures. Strategic Highway Res earch Program,Washington 1991

9. [9] Grube, H.: Ursache des Schwindens von Beton und Auswirkungen auf Betonbauteile. Schriftenreihe der Zementindustrie, H. 52, Beton-Verlag GmbH, Düsseldorf 1991

10. [10] Springenschmid, R.: Die Ermittlung der Spannungen infolge von Schwinden und Hydratations wärme in Beton. Beton- und Stahlbetonbau 79 (1984) H. 10, S. 263-269 
11. [11] Janssen, D.: Moisture in Portland Cement Concrete. Transportation Research Record 1121 (1981) S. 40-44

12. [12] Pickett, G.: Shrinkage stresses in concrete. American Concrete Institute Journal17 (1946) H. 3, S. 165-204

13. [13] Blaine, R. L.: A Statistical Study of the Effects of Trace Elements on the Properties of Portland Cement. Proc. 5th Int'l Symp. Chemistry of Cement, Tokyo1968, Vol. III, S. 8691

14. 26] Tazawa, E.: Autogenous Shrinkage of Concrete. Proceedings of International Workshop organized by JCI, Hiroshima, June 1998

15. [27] Hobbs, D. W.: Influence of Aggregate Restraint on the Shrinkage of Concrete. ACI Journal, September, pp.445-450, 1974

16. [39] Mehta,P.K"Properties of Portland Cement Concret Containing Fly Ash and silica fume",Cem,Concrete researches., 12,1982,pp683-696

17. [40]Ramachandran,V,S and Malhotra V,M "Superplastizers"Noyes Publication, Park Ridge, 1984

18. [42]Brameshuber,W"Selbstverdichtender Beton",Schriftenreiche Spezialbeton Band 5 ,verlag bau+Technik (in german),pp 20

19. [43] Bier T.A "Karbonatisierung und Realkalisierung von Zemnetstein und Beton",PhD thes is,massivbau,baustofftechnologie,TU Kalsruhe,Heft 4,1988 